\title{
Environmental and social impacts of wind energy: a view point with reference to India
}

\author{
Abhishek Gawande*, Pradeep Chaudhry \\ Indian Institute of Forest Management, Nehru Nagar, Bhopal, India-462003 \\ "e-mail: gawandeabhishek4@gmail.com; argawande19@iifm.ac.in
}

Received: 28 November 2018 / Accepted: 12 February 2019

\begin{abstract}
Energy is a basic requirement for economic development and is an integral part of every sector of Indian economy. Renewable energy is increasingly seen as the energy choice of the future as it offers an alternative yet effective solution to reduce carbon emissions and minimize the tradeoffs between environment and energy development. India is increasingly adopting responsible renewable energy technologies and taking positive steps towards carbon emissions, cleaning the air and ensuring a more sustainable future. A large body of literature addressing the issues regarding large negative environmental externalities caused by electricity generation from fossil fuels based energy is available; yet, literature dealing with environmental and social impacts of wind power energy plants, especially in developing countries like India is almost absent. This study is expected to contribute towards filling this gap by synthesizing information about the environmental and social impacts of the wind power projects especially in Indian context.
\end{abstract}

Key words: renewable energy, socio-economic impacts, environmental impact assessment, animal mortality risk, biodiversity conservation.

\section{Introduction}

Electric energy is one of the key factors for industrialization, urbanization, economic growth and improvement of quality of life in society. At present India is sixth largest country in the world in electricity generation, having total installed capacity of $343,899 \mathrm{MW}$ out of which $65 \%$ is from thermal, $13 \%$ from hydro, $2 \%$ from nuclear and the rest about 20\% is from renewable energy sources (Ministry of Power (MOP), 2018). Rapid Indian economic growth has contributed to today's quickly increasing demand for energy. However, conventional fossil fuels such as coal, oil and natural gas, which have been a primary energy source since the industrial revolution, are not only facing depletion, but has also gradually becoming a source for concern regarding its serious adverse effects on our environment (Leung \& Yang, 2012). Among available many renewable resources such as solar, wind, biomass, geothermal and solar-hydrogen energy, wind power is the only one that offers a mature technique, as well as promising commercial prospects, and is now generally applied in large-scale electricity generation (Deal, 2010). The government of India is promoting renewable energy (RE) as an effective tool to mitigate climate change besides enhancing energy security and enabling energy access. It has set an ambitious target of $175 \mathrm{GW}$ RE capacity to be achieved by the year 2022 (Kumar \& Thapar, 2017).

Though India is the sixth largest producer of electricity but the power produced from the country is mostly from coal and it is estimated that country's coal reserves would get exhausted by 2040-50 (Manohar \& Jayaprakasam, 2010). In addition, there is a growing international pressure on India to reduce emissions since India features among the top 5 contributors to greenhouses gas emissions. On 
top of this, more than 300 million people in India are still without access to electricity (NITI Aayog, 2015). Thus, it becomes important for a developing and populous country like India to concentrate on alternative renewable forms of energy. Renewable energy sources and technologies is one of the vital options to meet this requirement. Hence, there is a growing demand for the promotion of renewable energy since it has the tremendous potential to meet the increasing energy demands in a sustainable manner (Indian Institute of Technology Kanpur (IITK), 2016).

Globally, wind power is one of the fastest growing renewable energy source and has a high potential to become a primary source of energy in the future. According to statistics published by World Wind Energy Association (WWEA), the overall global wind power capacity by the end of 2017 reached $539 \mathrm{GW}$. The five global leaders in wind energy are China (188 GW), the US (89 GW), Germany (56 GW), India (32.9 GW) and United Kingdom $(17.9 \mathrm{GW})$. Their cumulative share is 71 per cent of the global wind power installed capacity (WWEA, 2018). As per the Indian Wind Energy Association, the wind energy potential is far from exhausted and the unexploited resource availability has the tremendous potential to not only meet India's energy demands in the years to come, but also to reduce India's energy poverty. India has total wind power potential of around 302,251 MW, but the current installed capacity is of only 34,132 MW (Ministry of New and Renewable Energy (MNRE), 2016). Top three states include Tamil Nadu, Maharashtra and Madhya Pradesh with highest untapped wind power potential (Table 1).

Table 1. Top three Indian states and all country in wind power potential

\begin{tabular}{|c|c|c|}
\hline State & $\begin{array}{c}\text { Wind potential } \\
\text { (MW) }\end{array}$ & $\begin{array}{c}\text { Installed } \\
\text { capacity (MW) }\end{array}$ \\
\hline Tamil Nadu & 33,800 & 8,197 \\
\hline Maharashtra & 4,5394 & 4,784 \\
\hline Madhya Pradesh & 10,484 & 2,520 \\
\hline India & 302,251 & 34,132 \\
\hline
\end{tabular}

Knowing this fact aggressive efforts are being made to realize this enormous potential. However, the way in which wind power is being developed in the country does exert some environmental and socio-economic impacts on the surrounding community and the landscape. The current paper deals with environmental and social impacts of wind power generation in India and an analysis has been made with the help of primary as well as secondary data.

Though wind power projects are not resource intensive, do not pollute air or water and does not generate any hazardous or radioactive waste either. But these projects can exert significant environmental and socio-economic impacts during construction phase which involves site preparation, construction of access roads, tower erection and the construction of transmission lines. In particular, the potential long-term effects, although minor, cannot be ignored. Nevertheless, the impacts of wind turbines on our environment have not been well-established, and remain under debate (Leung \& Yang, 2012).

In addition, the environmental clearance process for wind power projects is not regulated much in India and does not come under the purview of Environmental Impact Assessment (EIA) too. As per the EIA notification of 2006, "EIA is not mandatory for a wind power project irrespective of the size of the wind farm, its installed capacity, number of turbines or the sensitivity of the project location" (Bhusan et al., 2013a). However, EIA is a prerequisite for setting up of a wind power project in other countries.

In this context, the main objective of the current study is to synthesize the information about the environmental and social impacts of wind power energy plants.

\section{Environmental impacts of wind power}

\subsection{Land diversion}

Wind power projects are land intensive and the amount of land required for the construction of wind farms generally depends on the wind speed, hub height and the technology in use. The proponents of the wind energy advance that wind farms do not require significant land area since a $3 \mathrm{MW}$ wind turbine requires only around $1600 \mathrm{~m}^{2}$ area. However, when the number of wind farms will increase dramatically to achieve the ambitious target of $60 \mathrm{MW}$ of wind power in India, it would get increasingly difficult to locate the potential sites for siting wind energy projects which don't come in conflict with the existing land use (Dimitris, 2012).

The project developers acquire land from farmers or through dealers or from state forest departments for lease. In a report by Ministry of New and Renewable Energy (MNRE), Government of India, during a rapid survey technique in few select sites in the states Tamilnadu and Maharashtra, it was observed that wind farms sited in Tamilnadu were developed on agricultural lands and the project sites in Maharashtra were taken on lease from the Maharashtra state forest department. Although the land diversion in Tamilnadu was not an issue since the farmers had sold the land willingly to the project developers and also the farmers were paid more than the market rate during land acquisition. But for the sites visited in Maharashtra, it was observed that although the land ownership was not with 
the community, but the project site was built in close vicinity to the village commons and covered with vegetation. Hence the project development at such a site has definitely reduced the quality and quantity of the common property resource available to the community (MNRE, 2013).

There are two glaring examples from Maharashtra state where protected forest areas were used for installation of wind mills without suitable precautions. First case pertains to Koyna wildlife sanctuary located in Western Ghats spread over $423 \mathrm{~km}^{2}$ area. The area is very rich in biodiversity and is a habitat for leopard (Panthera pardus), Indian bison (Bos gaurus), Indian giant squirrel (Ratufa indica), pangolins (Manis spp.), sloth bear (Melursus ursinus), mouse deer (Tragulus spp.) and wild dogs (Cuon alpinus). It is also a sensitive bird area as identified by Bird Life International and is a home to endangered species like the red-headed vulture (Sarcogyps calvus) and white stork (Ciconia ciconia). Owing to its ecological importance, government has proposed UNESCO to enlist it as a world heritage site. But surprisingly, a project to setup 205 windmills had been sanctioned to setup in a protected forest area. The installation of windmills entirely changed the face of the wildlife sanctuary and impacted the sanctuary's ecology. More than 500 trees have been cut in Navja village after 40 land deals were signed. The loud humming of wind turbines disturbed the birdlife and resulted in reduction of endangered species like the red-headed vulture and the white stork. The endemic and rare species like Koyna Toad and the rare Draco (gliding lizards) has not been seen around in many years as the windmills encroached its habitat (Goel \& Shrivastava, 2011). Second case pertains to Bhimashankar wildlife sanctuary of Western Ghats, Maharashtra. The spot is a global biodiversity hotspot, a home to around 300 species and a habitat of leopards, pangolins and Indian giant squirrel. The forest is also a home to Maharashtra's State animal, the Malabar Giant Squirrel (Ratufa indica). Surprisingly, in such an ecologically rich landscape, Maharashtra government approved to setup a $113 \mathrm{MW}$ wind power project by Enercon Company, spread over 14 villages of the Khed and Maval talukas, covering 194.66 hectares of reserve forest land. The project activities have led to substantial impacts on the surrounding flora and fauna. Though the project had permission to fell 26,615 trees but over 300,000 trees were felled for the construction of $20 \mathrm{~km}$ long access roads along the hills. Most trees felled were 30-50 years old, namely mahua (Madhuca longifolia), jamun (Syzygium cumini), wild mango (Mangifera indica) which were of significant economic importance to the local communities. The Giant Indian squirrel (threatened species) disappeared from the area.

Villagers' consent was not taken while setting up a project and they were illegally restrained from accessing the hills (Bhusan et al., 2013b).

\subsection{Biodiversity}

Wind power projects are generally sited on forest land or hilly areas or near the sea which disturbs the surrounding flora and fauna. The problem shoots up especially when wind farms are located inside forested areas since wide roads of around 10 meters width need to be constructed by cutting down forests. These access roads inside forests cause linear fragmentation of the ecosystems, increases the traffic that can hit or scare away animals and may open up wildlife areas for easier human exploitation. Moreover, the access roads passing through catchment areas affect the hydrology of the area by changing, blocking or silting the course of water streams (Bhusan et al., 2013b).

In case of hilly areas, the cuttings made into the sides of the hill for leveling the access roads are often many meters high, which cannot be scaled by animals whose migration and search for food is therefore hindered. There are instances where the wind farms posed restriction to wild animals, thereby forcing them to migrate to nearby villages which resulted in conflicts with people (Goel \& Shrivastava, 2011).

Also, blasting and other destructive activities carried out during the construction phase disturb the wildlife. Especially, the bird and bat deaths have been confirmed from wind projects, both in India and abroad (Pande et al., 2013; Stewart et al., 2005). As per the anecdotal evidence based on the observations by activists and locals, it was observed that the sound and vibration of wind turbines scares away grazing animals (Bhusan et al., 2013b). The cases of habitat destruction due to wind power projects are also reported in India. At Koyna wildlife sanctuary in the Western Ghats of Maharashtra, the endemic and rare species like Koyna Toad (Xanthophryne koynayensis) and the rare Draco (gliding lizards) has not been seen around in many years as the windmills encroached its habitat (Goel \& Shrivastava, 2011).

\subsection{Wildlife}

The rotating blades of wind turbines pose mortality and disturbance risks to the birds. The ancillary infrastructure created to produce electricity also causes disruption to the free wildlife movement. The evidences from the several international studies show that the likelihood of collision mortality for birds is highly dependent on the location of wind farms and the characteristics of the bird species. Species that fly at rotor height are at a greater risk than those that fly at below or above rotor height. Similarly, other factors such as the proximity of wind farms to feeding and breeding habitats, and whether the wind farms are located in migration paths will have a significant impact on the collision mortality of birds. In the study conducted at United States, it was estimated that on an average 234,000 birds 
were killed annually by wind turbine operations (Loss et al., 2013; Saidur et al., 2011).

There is growing evidence that the bird density gets affected around wind farm site. A study conducted in UK revealed that during construction phase of wind farms, densities of the species red grouse (Lagopus lagopus scoticus), snipe (Gallinago gallinago) and curlew (Numenius arquata) declined drastically. Moreover, after the construction phase too, the densities of the species curlew were found to be lower than the reference sites (Abbasi et al., 2014). The bird mortality rate is increased in the areas close to the bird migration routes since the wind turbines create physical barriers that obstruct their natural route (Langston \& Pullan, 2003). As a result, the birds deviate from their usual route in order to avoid the wind farms. As per one of the visual and radar observational study conducted at Horns Rev offshore wind farm in Denmark, it was observed that around $14-22 \%$ of the birds increased their flying altitude to pass through the wind farm and many birds also changed their flying direction to bypass the wind farm by a distance of 400-1,000 m (Christensen et al., 2004). The extra deviation work increases their energy expenditure and subsequently increases their mortality rates (Garvin et al., 2011).

There has been relatively little research in India on the impact of wind turbines on birds, thus making it difficult to estimate the likely bird collision deaths due to wind farm operations. A two-year study was conducted at Bhambarwadi Plateau in northern Western Ghats, Maharashtra to assess the impact of wind farms on birds which included 10 wind turbines spread in $0.5 \mathrm{~km}^{2}$ area. The plateaus on the Western Ghats are one of the key site and global biodiversity hotspot where wind velocities are encountered throughout the year (Myers et al., 2000). During the tenure of study between July 2008 and June 2010, 19 birds and mammals were found dead due to collision with rotor blade or electrocution due to contact with overhead transmission lines or transformers. The study revealed that the annual average collision rate was 1.9 birds per turbine (Pande et al., 2013). In Gujarat, Electrocution from power lines is a common concern for the birds, where over 150 flamingo deaths near their breeding grounds have been reported (Paliwal, 2011). In a similar instance at a wind power project in Koyna wildlife sanctuary, Maharashtra, which is an important bird area as notified by Bird Life International and is a habitat of endangered bird species like white stork and red-headed vulture, cases have been reported about the disruption of birdlife due to wind farm activities (Goel \& Shrivastava, 2011).

Bats are subjected to higher mortality rates from wind farms as compared to birds since bats get more attracted to moving objects than stationary ones (Philip et al., 1978). Around one fourth of all bat species in the United States and Canada got affected by wind turbine operations (Ellison, 2012). Wind turbines not only killed the local popu- lation of bats but also the migratory ones (Bernard et al., 2014). In one of the studies conducted in North America to assess the bat fatalities, it was observed that the height of the turbine tower affects the bat mortality rates. Bat fatalities increased exponentially with the increase in tower height. This is a new challenge as far as the bat mortality rates from wind farms are concerned since wind energy is a rapidly growing sector and the future wind farms will have lesser number of wind turbines but each wind turbine will be taller in size (Barclay et al., 2007).

The cases of bat mortality due to electrocution by transmission wires and transformer stations have also been observed in India. The establishment of wind farms in areas like Western Ghats which is supposed to be a biodiversity hotspot and home to many threatened bat species is a growing concern (Pande et al., 2013). Another growing concern is the amount of high heat radiation by the wind turbine nacelles which attract a large number of insects. This in turn causes the hunting bats to aggregate near wind turbines thus posing a threat to their survival (Long et al., 2010).

\subsection{Marine ecology}

The constructional and operational activities in offshore wind farms can severely affect the marine wildlife. The maintenance activities such as lubrication or parts replacement pollute the seawater. The wind farm activities also create an artificial reef which affects the marine biodiversity. The construction of wind turbine foundations and erection of wind turbine towers makes the seawater turbid and changes the fish distribution near the wind turbine (Dai et al., 2015). The noise and electromagnetic fields coming out of the wind turbines affects the fish (Kikuchi, 2009). One of the studies at the Nysted Offshore Wind Farm, wherein the researchers observed a clear decline in porpoise population over a period of two years during construction and operation activities of the wind farm (DONG Energy et al., 2006). Though India is yet to establish offshore wind farms and tap the wind potential from seas, but India's push for offshore wind power has been gaining momentum over the years. India possesses an estimated $127 \mathrm{GW}$ of offshore wind power potential mostly off the coasts of Maharashtra, Gujrat and Tamil Nadu (Sushma, 2013). Thus, it becomes important to plan for such enormous potential of offshore wind power projects right from the planning phase so that it does not affect the marine ecosystem.

\subsection{Climate change}

There are growing evidences of the fact that wind farms cause significant environmental impact on the local climate as the wind farms becomes larger and larger in size (Abbasi et al., 2014). In a study at San Gorgonio wind fields in the US, Roy and Traiteur found that the giant wind farms 
can change the local surface air temperatures in the vicinity of the site (Roy \& Traiteur, 2010). They found that the giant wind turbines warm surface temperatures at night and cool in daytime (David, 2010). Wang and Prinn (2010) estimated that the global temperature would increase by 1 degree Celsius if $10 \%$ of global energy demand came from wind power in 2100. According to the findings of eight-year satellite study during 2003-2011 over regions of west-central Texas involving 2358 turbines, a significant temperature increases of $0.724^{\circ} \mathrm{C}$ was reported in the area (Zhou et al., 2012).

\section{Socio-economic impacts of wind power}

\subsection{Noise pollution}

As per the Ministry of Environment Forest and Climate Change (MOEF \& CC), Government of India's guidelines for wind power projects located in forest areas: "The turbine of the wind mill produces a humming sound, which may cause disturbance for the avian habitat" (MOEF \& CC, 2004). When operational, the wind turbines generate noise which can disturb the nearby communities and as per the MOEF guidelines, wind farms should not be established closer than 300 meters from habitation. However, this is not mandated and there are no requirements to monitor noise from wind turbines (Bhushan et al., 2013a).

The noise coming out of the wind farms includes aerodynamic noise and mechanical noise. Aerodynamic noise comes from the turbine blades, whereas mechanical noise comes from the turbine's gearbox, the generator and other auxiliary parts. These noises are irritating and annoying and disturb the people residing in the vicinity of wind farms. Such noises can also cause serious health problems such as headaches, hearing loss and sleep disturbance in humans (Leung \& Yang, 2012). In a cross-sectional study conducted in New Zealand, on effect of wind turbines noise on neighbor's wellbeing, it was observed that wind turbines affect the quality of life and residents developed a virulent attitude against wind turbine projects (Shepherd et al., 2011).

\subsection{Shadow flicker}

Shadow flicker is the negative impact associated only with the case of wind energy. This effect occurs when the sunlight or some another strong source of light falls on the turbine blades and it occur three times per rotation since most wind turbines have three blades. When the blades are rotating, a flicker is generated which causes feelings ranging from undesirable to unbearable $(\mathrm{CMOH}, 2010)$. The magnitude of shadow flicker effect is dependent on day time and wind speed. The effect is maximum during sun- rise and sunset when the shadows are longest and also at high wind speeds (Bhusan et al., 2013a). There is anecdotal evidence that shadow flicker result in health problems such as headaches and stress and it may also scarce away livestock (Bhusan et al., 2013b). Such impacts of shadow flicker cause people to have a negative attitude towards wind farms (Finnveden et al., 2009).

\subsection{Community land issues}

Much of the land cleared for the construction of wind farm projects is a forested land on which majority of the surrounding communities depend for their subsistence. So, establishment of wind farm projects in such areas may cause significant impact to these indigenous communities since they do not hold formal land rights over such areas. Many times, it is observed that the wind power installation companies encroach over community lands, acquire the land illegally and pay very less compensation. In one such case by Sarjan Realities in Kerala, it was reported that the company was buying and encroaching upon tribal land by misleading the tribals to install windmills for Suzlon energy. The company bought 60 ha tribal land on which the 36 indigenous tribals were paying tax for the land. One of the committee member of the Adivasi Samrakshana Samithi that works for the rights of tribals told that the "Middlemen buy land from tribals at very low prices or they grab land by forging papers. Then they transfer it to the companies" (Suchitra, 2011). This is a violation of the Kerala Restriction on Transfer by and Restoration of Lands to Scheduled Tribes Act, 1999 as non-tribals cannot buy land from tribals in Kerala (Bhusan et al., 2013a).

There are also incidences of loss of livelihood because of wind project sites. In the Wind power project setup by Enercon Ltd in Bhimashankar wildlife sanctuary it was observed that villagers lost their livelihood because of felling of valuable tree species such as mahua, beheda, jamun, chaar (Buchanania cochinchinensis) and wild mango (Aparna, 2011).

The 2,833 ha forest generated by local communities on revenue wasteland since two decades was destroyed to setup Enercon company's $20 \mathrm{MW}$ wind power project In Andhra Pradesh, India. The restored kalpavali region of the state was rich in terms of both flora and fauna with 264 floral and 105 faunal species and it also provided livelihoods to around 400 families. But the face of the Kalpavali forest which people painstakingly generated and protected got changed drastically after Enercon's entry to setup wind power project resulting in both environmental and socioeconomic impacts on the surrounding landscape. Large numbers of trees were cut, vegetation cover has been lost and hilltops are being cut for installing windmills. The deep cuts of about 3-4 m were made on slopes to develop access roads resulted in massive soil erosion (Fig. 1). The 
local Mushtikvolia water tank got silted due to construction activities (Suchitra, 2011). Similarly, in one of the sites located in the state of Madhya Pradesh the construction of wind farms and the mining activities in the surrounding areas raised the tensions between the project developers and local residents (Fig. 2).

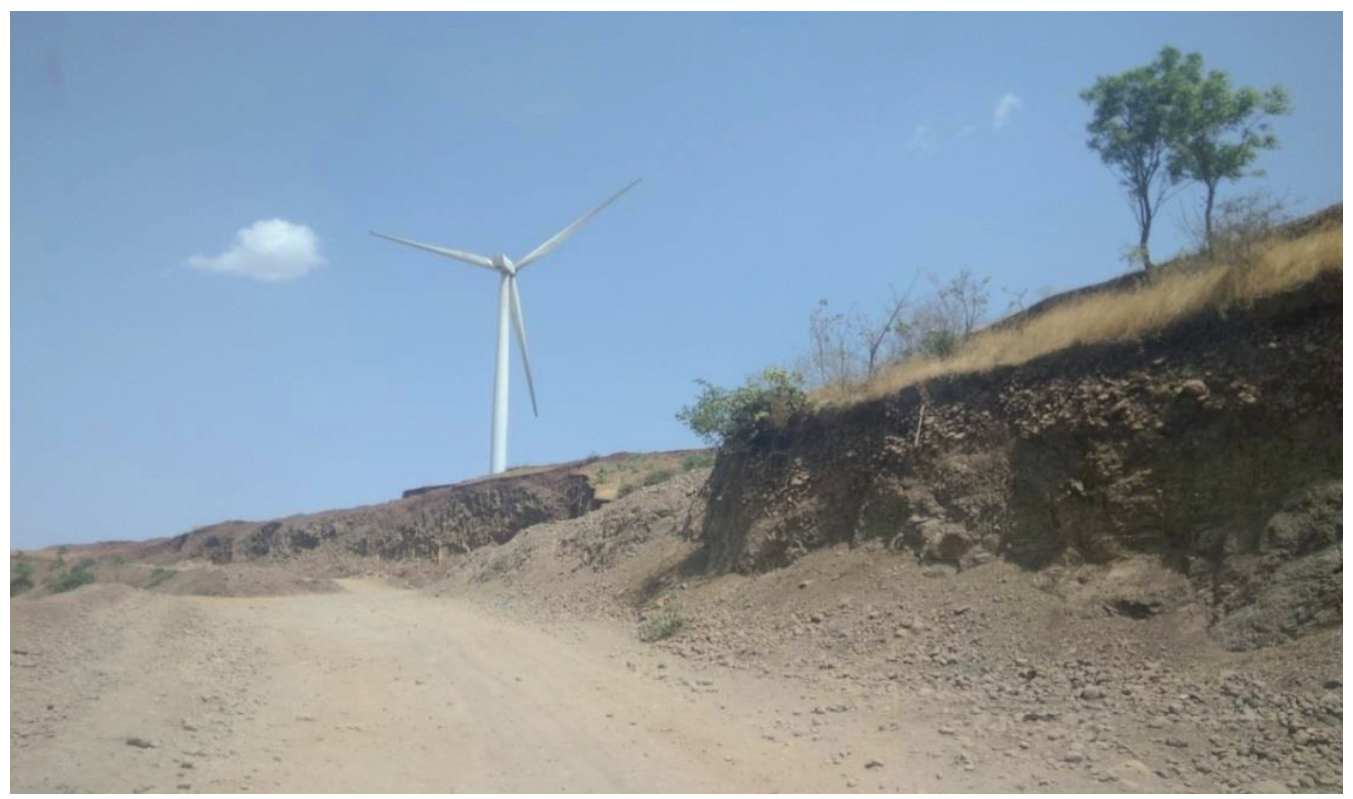

Figure 1. Forest clearance and massive soil erosion due to hill side cutting (photo: Abhisek Gawande)

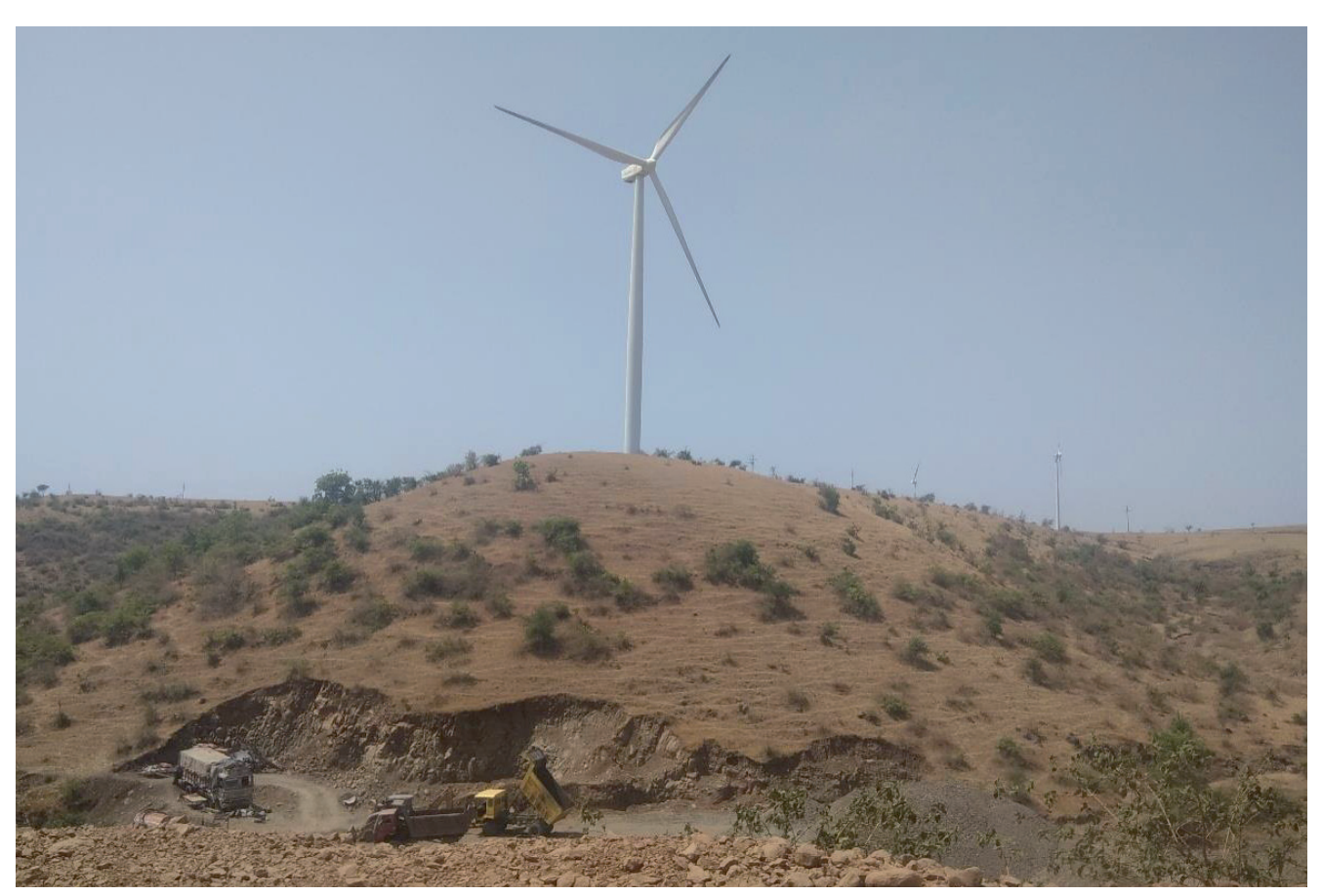

Figure 2. Mining activities exacerbating the existing problems (photo: Abhisek Gawande)

\section{Conclusion}

Although wind power is believed to be environmentally benign, compared to conventional fossil fuels, it still has effects on animals and on human life, such as noise and visual impacts. But off late, its climatic impact has drawn 
particular attention. These impacts may seem minor at present, but its potential long-term effects are not yet known, and thus cannot be ignored (Leung \& Yang, 2012). Though the environmental impact of wind energy systems is a controversial topic, yet the literature review and outcome of the field visits confirms that the wind energy systems have potential negative impacts too besides being a clean and green renewable source of energy. These issues may seem minor at present in Indian situation, but it may cause disastrous effects in the future when wind energy systems become the main sources of energy. This is not to discourage or discard the renewable energy development. Only thing is that they should be carried out after proper assessment of their environmental and socio-economic impacts.

The negative impacts could be minimized with appropriate measures. The developers and regulatory authorities should take into account the dependence of local populations upon natural resources for their livelihood while encouraging renewable energy development. Some probable solutions also include making EIA studies mandatory for all renewable energy projects; giving greater powers to the village level panchayats; providing employment to locals and ensuring electricity access for the people who live in vicinity of renewable energy projects.

In short, the environmental impact of wind turbines is a controversial topic. As wind energy will become a main energy source in the near future, many environmental effects that now seem minor may cause disastrous impacts in the future, and therefore should not be ignored (Leung \& Yang, 2012). Therefore, we recommend further research should be carried out, making wind power a friendly and sustainable way to generate electricity. At present India lack the necessary planning framework and the renewable energy development is taking place in an unplanned, project-by-project fashion that fails to account for landscapescale implications. Greater emphasis needs to be given on holistic and scientific planning of the landscape to avoid or minimize the negative impacts of renewable energy development on the surrounding people and the environment.

\section{Acknowledgments}

This research is part of the summer internship work carried out with The Nature Conservancy (TNC) and we are thankful to Mr. Dhawal Negandhi, Ecological Economist, TNC, who provided insight and expertise that greatly assisted the research.

\section{References}

Abbasi T., Premalatha M., Abbasi T. \& Abbasi S.A., 2014, Wind energy: Increasing deployment, rising environ- mental concerns. Renewable and Sustainable Energy Reviews 31: 270-288.

Aparna P., 2011, Wind farm threat to forests. Down to Earth, A publication by CSE magazine, New Delhi.

Barclay R.M.R., Baerwald E.F. \& Gruvera J.C., 2007, Variation in bat and bird fatalities at wind energy facilities: assessing the effects of rotor size and tower height. Canadian Journal of Zoology 85(3): 381-387

Bernard E., Paese A., Machado R.B. \& de Souza Aguiar L.M., 2014, Blown in the wind: bats and wind farms in Brazil. Natureza \& Conservação 12(2): 106-111.

Bhushan C., Singh S.K., Sambyal S.S. \& Agrawal K.A., 2013a, EIA Guidelines Wind Power. Centre for Science and Environment, Delhi.

Bhushan C., Hamberg J. \& Agrawal K.K., 2013b, Green Norms for Wind Power. Centre for Science and Environment, Delhi.

Christensen T.K., Hounisen J.P., Clausager I. \& Petersen I.K., 2004, Visual and radar observations of birds in relation to collision risk at the Horns Rev offshore wind farm. NERI report by National Environmental Research Institute. Ministry of the Environment Denmark, Copenhagen.

Chief Medical Officer of Health (CMOH) Report, 2010, The Potential Health Impacts of Wind Turbines. Proceedings of the European wind energy conference, Ontario.

Dai K., Bergot A., Liang C., Xiang W.N. \& Huang Z., 2015, Environmental issues associated with wind energy - A review. Renewable Energy 75: 911-921.

David B., 2010, How Wind Turbines Affect Your (Very) Local Weather. Scientific American, October 4, 2010.

Deal W.F., 2010, Wind power: an emerging energy resource. Technology and Engineering Teacher 9: 9-15.

Dimitris K.A., 2012, A review of the environmental and human impacts from wind parks. A case study for the Prefecture of Lasithi, Crete. Renewable and Sustainable Energy Reviews 16(5): 2850-2863.

DONG Energy, Vattenfall, Danish Energy Authority \& Danish Forest and Nature Agency, 2006, Danish Offshore Wind: Key Environmental Issues. Published by DONG Energy, Vattenfall, The Danish Energy Authority and The Danish Forest and Nature Agency.

Ellison L.E., 2012, Bats and wind energy-A literature synthesis and annotated bibliography. U.S. Geological Survey Open-File Report 2012-1110.

Finnveden G., Hauschild M.Z., Ekvall T., Guinée J., Heijungs R., Hellweg S., Koehler A., Pennington D. \& Suh S., 2009, Recent developments in Life Cycle Assessment. Journal of Environmental Management 91(1): $1-21$.

Indian Institute of Technology Kanpur (IITK), 2016, Developments in Renewable Energy- Current Trends \& Future Prospects. Power Market in India - Way For- 
ward. A working paper, 2nd March 2016. IIT Kanpur, Uttar Pradesh, India.

Garvin J.C., Jennelle C.S., Drake D. \& Grodsky S.M., 2011, Response of raptors to a windfarm. Journal of Applied Ecology 48: 199-209.

Goel G. \& Shrivastava S.K., 2011, Koyna sanctuary plundered. Down to Earth. A publication by CSE magazine, Delhi.

Kikuchi R., 2009, Risk formulation for the sonic effects of offshore wind farms on fish in the EU region. Marine Pollution Bulletin 60(2):172-177.

Kumar A. \& Thapar S., 2017, Addressing Land Issues for Utility Scale Renewable Energy Deployment in India. A Report by TERI School of Advanced Studies, Plot No. 10 Institutional Area Vasant Kunj, New Delhi - 110 070, India.

Langston R.H.W. \& Pullan J.D., 2003, Windfarms and birds: an analysis of the effects of wind farms on birds, and guidance on environmental assessment criteria and site selection issues. Report T-PVS/Inf (2003) 12, by BirdLife International to the Council of Europe, Bern Convention on the Conservation of European Wildlife and Natural Habitats. RSPB/BirdLife in the UK.

Leung D.Y.C. \& Yang Y., 2012, Wind energy development and its environmental impact: A review. Renewable and Sustainable Energy Reviews 16: 1031- 1039.

Long C.V., Flint J.A. \& Lepper P.A., 2010, Insect attraction to wind turbines: does colour play a role? European Journal of Wildlife Research 57 (2):323-331.

Loss S.R., Will T. \& Marra P.P., 2013, Estimates of bird collision mortality at wind facilities in the contiguous United States. Biological Conservation 168: 201-209.

Manohar D P J and Jayaprakasam Dr. T., 2010, Solar Energy for Green India. International Journal of Research Granthaalayah 4: 21-24.

Ministry of Environment Forest and Climate Change (MOEF \& CC), 2004, (http://forestsclearance.nic.in/ writereaddata/public_display/schemes/2146926545\$gu ildeline \%202.pdf).

Myers N., Mittermeier R.A., Mittermeier C.G., da Fonseca G.A. \& Kent J., 2000, Biodiversity hotspots for conservation priorities. Nature 403(6772): 853-858.

Ministry of Power (MOP), 2018, (https://powermin.nic.in/ en/content/power-sector-glance-all-india), [Accessed Aug 6, 2018].

Ministry of New and Renewable Energy (MNRE), 2013, Developmental Impacts and Sustainable Governance Aspects of Renewable Energy Projects.
Ministry of New and Renewable Energy (MNRE), 2016, State wise \% of Wind Potential Utilized (As on 31.03.2016). MNRE, Delhi.

NITI (National Institution for Transforming India) Aayog, 2015, Report of the Expert Group on $175 \mathrm{GW}$ RE by 2022, Government of India, New Delhi.

Paliwal A., 2011, Killing ground. Down to Earth, A publication by CSE magazine, New Delhi.

Pande S., Padhye A., Deshpande P., Ponkshe A., Pandit P., Pawashe A., Pednekar S., Pandit R. \& Deshpande P., 2013, Avian collision threat assessment at 'Bhambarwadi Wind Farm Plateau' in northern Western Ghats, India. Journal of Threatened Taxa 5(1): 3504-3515.

Philip H, Jen S \& McCarty J.K., 1978, Bats avoid moving objects more successfully than stationary ones. Nature 275: 743-744.

Roy S.B. \& Traiteur J.J., 2010, Impacts of wind farms on surface air temperatures. Proc. Natl. Acad. Sci. USA 107(42): 17899-17904.

Saidur. R., Rahim N.A., Islam M.R. \& Solangi K.H., 2011, Environmental impact of wind energy. Renewable and Sustainable Energy Reviews 15(5): 2423-2430.

Shepherd D., McBride D., Welch D., Dirks K. \& Hill E., 2011, Wind turbine noise and health-related quality of life of nearby residents: A cross-sectional study in New Zealand. The Fourth International Meeting on Wind Turbine Noise, 12-14 April 2011, Rome, Italy.

Stewart G.B., Pullin A.S. \& Coles C.F., 2005, Effects of Wind Turbines on Bird Abundance. CEE review 04002. Centre for Evidence-Based Conservation - School of Biosciences, The University of Birmingham, Edgbaston -Birmingham, B15 2TT, UK.

Suchitra M., 2011, Suzlon windmills on tribal land. Down to Earth. A publication by CSE magazine, New Delhi.

Sushma U.N., 2013, India is finally moving to tap the wind energy potential on its seas. QUARTZ India, publication April 13, 2013.

Wang C. \& Prinn R.G., 2010, Potential climatic impacts and reliability of very large-scale wind farms. Atmos. Chem. Phys. 10: 2053-2061.

World Wind Energy Association (WWEA), 2018, Wind power capacity reaches $539 \mathrm{GW}, 52.6 \mathrm{GW}$ added in 2017. WWEA, Bonn.

Zhou L., Tian Y., Roy S.B., Thorncroft C., Bosart L.F. $\& \mathrm{Hu}$ Y., 2012, Impacts of wind farms on land surface temperature Nature Climate Change 2(7): 539-543. 